\title{
The effect of breed, sex and aging time on tenderness of beef meat
}

\author{
Š́rka Hanzelková ${ }^{1}$, Jana Simeonovová ${ }^{1}$, David Hampel ${ }^{1}$, Aleš Dufek ${ }^{2}$, Jan Šubrt ${ }^{1}$ \\ ${ }^{1}$ Department of Food Technology, Agronomic Faculty, Mendel University in Brno, \\ Czech Republic, \\ ${ }^{2}$ Agriresearch Rapotin Ltd., Vikyrovice, Czech Republic
}

Received April 20, 2010

Accepted September 21, 2010

\begin{abstract}
Our study was conducted to determine the effect of production factors (breed, sex) and aging time on the textural properties of beef using instrumental measurement of tenderness. Meat was obtained from Galloway, Simmental, Charolais, Czech Fleckvieh breeds and their crossbreeds. Meat was either unaged or aged for 14,28 or 42 days. The tenderness was characterized by Warner-Bratzler test and compression test using Tira-test device. The cooking loss of meat juice was also evaluated. Analysis of variance at 5\% significance level showed that tenderness was influenced by all tested factors (breed, sex, aging time). The shear force decreased with aging of meat. The correlation between shear force and compression test was $0.257(p \leq 0.001)$. The differences in tenderness were found among breeds. The highest initial shear force was measured in Simmental $(151.98 \mathrm{~N})$. Compression test showed better tenderness in Czech Fleckvieh and Galloway than in Simmental, Charolais and crossbreeds. Meat from bulls was significantly $(p \leq 0.001)$ less tender than from heifers. There was a significant $(p \leq 0.001)$ increase of cooking loss of meat juice during aging from $25.3 \%$ after slaughter to $34.0 \%$ after aging period. The research results could be useful for determination whether specific cattle breeds can produce tender meat with good aging patterns. According to findings of the current study it is especially necessary to emphasize that factor of aging time exceeded the influence of breed and sex on tenderness. The study also suggests extending of aging period to 6 week to assure tenderness of beef.
\end{abstract}

Texture, bulls, heifers, WBSF, compression test

Tenderness of meat is a well-known issue to be solved by the scientific community and industry. As the beef annual consumption in the Czech Republic is as high as $9.4 \mathrm{~kg}$ per capita in the year 2009 (Czech Statistical Office 2010), it is important to control its tenderness related to the consumer palatability.

The tenderness of beef is the attribute most demanded by consumers and its improvement is the primary reason for post-mortem aging (Parrish 2009). Many authors conducted studies on beef tenderness (Koohmaraie 1994; Lu et al. 1999; Oliete et al. 2005; Lepetit 2008; Brewer et al. 2008) indicating many variables that affect meat properties, including post-mortem aging. Meat aging is a process involving post-mortem proteolysis of myofibrillar proteins in muscles. Tenderisation begins shortly after slaughter and increases after the rigor mortis phase (Koohmaraie et al. 1995). To improve the consistency of meat quality with respect to tenderness, beef should be aged at least 14 days (in practice carcasses tend to be aged only for 5 days). Meat that is aged beyond this time may develop 'off' odours and give the beef 'liver' taint.

Meat tenderness is influenced by the genetic makeup of cattle and therefore there is major interest in genetic selection in order to decrease problems with meat tenderness variation. Koohmaraie et al. (1995) reported several breeds (Jersey, Pinzgauer, South Devon, and Piedmontese) that produce more tender meat than other breeds. The relation of beef tenderness to sex has been studied earlier (Hedrick et al. 1969; Prost et al. 1975; Wulf et al. 1996, Pipek et al. 2003; Jeleníková et al. 2008).

The most widely used instrumental test for meat tenderness evaluation is Warner-Bratzler shear test (Belew et al. 2003; Bratcher et al. 2005). Only few authors used compression 
test (Caine et al. 2003; Sochor et al. 2005; Ruiz de Huidobro et al. 2005), some only for raw meat evaluation (Maria et al. 2003; Sanudo et al. 2004).

The aim of our analysis was to evaluate the influence of aging time on the texture of beef by WBSF and compression tests to assess correlation between the values obtained from both measuring methods and to predict the effects of breed and sex on beef tenderness.

\section{Materials and Methods}

Muscullus longissimus lumborum et thoracis (MLLT) was obtained from bulls and heifers (523 to 795 day of age; $n=72$ ) originated from the Agriresearch Rapotin Ltd. Animals represented the breeds of Galloway (GA; 19 animals), Simmental (SI; 5 animals), and Czech Fleckvieh (CF; 6 animals), Charolais (CH; 21 animals), and crossbreeds (X; 21 animals) - progeny of a hybrid sire. Muscle MLLT was removed from the right side of each carcass. The muscle was divided into 4 sections. The first section was evaluated $48 \mathrm{~h}$ post-mortem. The remaining ones were vacuum-packaged and stored at $4{ }^{\circ} \mathrm{C}$ until aged for 14,28 and 42 days.

The muscle was trimmed of outside fat and connective tissue, weighed and vacuum packaged before cooking. Samples were cooked at a constant temperature of the water bath to obtain an internal temperature target of $70{ }^{\circ} \mathrm{C}$ for $1 \mathrm{~h}$. After cooking, samples were cooled in water bath to the temperature of $20^{\circ} \mathrm{C}$, blotted with a paper towel and weighed. The cooking loss was determined as follows:

$$
\text { Cooking loss }[\%]=\frac{(\text { weight of raw meat- weight of cooked meat })}{\text { (weight of raw meat) }} \times 100
$$

Stripes with an edge length of $10 \mathrm{~mm}$ and 15 cubes with an edge length of $10 \mathrm{~mm}$ were prepared from each sample for Warner-Bratzler test and compression evaluation, respectively.

The laboratory device Tira-test 27025 (TIRA Maschinenbau GmbH, Germany) was used to analyse the samples. Tenderness was analysed by two objective methods - Warner-Bratzler shear force test (WBSF) with crosshead speed of $50 \mathrm{~mm} \cdot \mathrm{min}^{-1}$ and uniaxial compression tests with $80 \%$ compression and crosshead speed 100 $\mathrm{mm} \cdot \mathrm{min}^{-1}$. Maximum force required to shear $(\mathrm{N})$ or to compress $\left(\mathrm{N} \cdot \mathrm{cm}^{-2}\right)$ the sample was recorded and defined as tenderness.

Statistical analysis of the data was done by means of the statistical data analysis software Genstat 9.2. The data were analysed by 3-way analysis of variance to evaluate effects of aging time, breed and sex. Statistical prediction (estimated average value of concrete level of a factor) was calculated. Interactions and main effects were considered significant at $5 \%$ significance level $(p \leq 0.001)$.

\section{Results}

\section{Warner-Bratzler test}

Table 1. Predicted mean values of Warner-Bratzler tenderness of beef meat selected by aging time and by breed

\begin{tabular}{cccc}
\hline Aging time (weeks) & $\begin{array}{c}\text { Warner-Bratzler } \\
\text { tenderness prediction }(\mathrm{N})\end{array}$ & Breed & $\begin{array}{c}\text { Warner-Bratzler } \\
\text { tenderness prediction }(\mathrm{N})\end{array}$ \\
\hline 0 & $133.12 \pm 0.94^{\mathrm{a}}$ & Czech Fleckvieh & $88.72 \pm 1.66^{\mathrm{b}}$ \\
2 & $86.45 \pm 0.94^{\mathrm{b}}$ & Charolais & $99.19 \pm 0.95^{\mathrm{c}}$ \\
4 & $77.46 \pm 0.94^{\mathrm{c}}$ & Galloway & $73.32 \pm 1.05^{\mathrm{a}}$ \\
6 & $67.93 \pm 0.94^{\mathrm{d}}$ & Simmental & $126.82 \pm 1.87^{\mathrm{d}}$ \\
& & Crossbreeds & $92.77 \pm 0.88^{\mathrm{e}}$ \\
\hline
\end{tabular}

Means with different superscript are significantly different $(p \leq 0.001)$

Three-way analysis of variance showed that all of the examined factors (breed, sex, and aging time) were significant at 5\% significance level for the maximum WBSF. Predicted mean values for aging time are displayed in Table 1 . The least significant difference for all predictions $(p \leq 0.001)$ is $2.612 \mathrm{~N}$, which indicates large influence of aging on beef tenderness. Table 1 shows also predictions for breeds. Five breeds involved in this study provided beef with significantly different tenderness. The extent of tenderness increase was also influenced by breed. The values obtained from all measurements show the lowest WBSF value for Galloway and obviously higher value for Simmental. The average 
WBSF values at aging intervals according to the breeds are presented in Table 2. Czech Fleckvieh breed produced very tough beef at rigor mortis state. The highest initial shear force was measured in Simmetal and this breed indicated low increase of tenderness in association with aging. Its initial WBSF was high and there was only small development in texture even after six weeks of aging. Dissimilar aging pattern was observed in Czech Fleckvieh with great development of tenderness. Charolais, Galloway and crossbreeds had comparatively lower initial tenderness and after 6-week aging the tenderness was on the equal low level.

Table 2. Warner-Bratzler tenderness of beef meat of different breeds during different aging time

\begin{tabular}{lcrrr}
\hline $\begin{array}{l}\text { Aging time (weeks)/ } \\
\text { Warner-Bratzler } \\
\text { tenderness (N) }\end{array}$ & 0 & 2 & 4 & 6 \\
\hline Simmental & $151.98 \pm 20.88$ & $124.24 \pm 30.70$ & $115.68 \pm 36.59$ & $103.78 \pm 29.45$ \\
Czech Fleckvieh & $143.68 \pm 24.63$ & $105.16 \pm 39.99$ & $63.21 \pm 31.92$ & $57.37 \pm 30.52$ \\
Charolais & $137.84 \pm 18.42$ & $84.91 \pm 32.08$ & $81.70 \pm 32.48$ & $66.80 \pm 24.94$ \\
Crossbreeds & $128.14 \pm 21.56$ & $84.49 \pm 39.47$ & $81.72 \pm 39.59$ & $72.99 \pm 36.06$ \\
Galloway & $122.99 \pm 30.31$ & $76.58 \pm 26.55$ & $64.36 \pm 28.41$ & $59.65 \pm 28.50$ \\
\hline
\end{tabular}

Table 3. Predicted mean values of compression tenderness of beef selected by aging time and breed

\begin{tabular}{cccc}
\hline Aging time (weeks) & $\begin{array}{c}\text { Compression tenderness } \\
\text { prediction }\left(\mathrm{N} \cdot \mathrm{cm}^{-2}\right)\end{array}$ & $\begin{array}{c}\text { Compression tenderness } \\
\text { prediction }\left(\mathrm{N} \cdot \mathrm{cm}^{-2}\right)\end{array}$ \\
\hline 0 & $244.0 \pm 2.76^{\mathrm{a}}$ & Czech Fleckvieh & $205.8 \pm 4.64^{\mathrm{a}}$ \\
2 & $229.2 \pm 2.76^{\mathrm{b}}$ & Charolais & $242.4 \pm 2.72^{\mathrm{b}}$ \\
4 & $230.8 \pm 2.64^{\mathrm{b}}$ & Galloway & $214.4 \pm 2.97^{\mathrm{a}}$ \\
6 & $225.5 \pm 2.64^{\mathrm{b}}$ & Simmental & $257.0 \pm 6.14^{\mathrm{b}}$ \\
& & Crossbreeds & $242.3 \pm 2.46^{\mathrm{b}}$ \\
\hline
\end{tabular}

Means with different superscript are significantly different $(p \leq 0.001)$

\section{Compression test}

Analogously to the WBSF test, the statistical analysis of compression test results confirmed all factors were significant at a $5 \%$ level. Predicted values for mean aging time (Table 3) suggest that only tenderness of fresh beef (at rigor mortis state) differs significantly $(p \leq 0.001)$ from other measurements during aging. The compression test did not detect differing texture of beef during aging as discovered by the WBSF test. Breeds influenced tenderness as well. Predicted mean values are shown in Table 3. There were no significant differences in the tenderness of meat in Czech Fleckvieh and Galloway and less tenderness was found in Simmenthal and Charolais breeds and crossbreeds. Table 4 describes the mean values of tenderness divided by breeds during various aging stages. The values of tenderness changing during aging time are in accordance with statistically predicted values. As mentioned above, in case of the compression test the aging time was not as confirmative factor of tenderness as in WBSF measurements. This conclusion is noticeable from averaged values in Table 4 as well.

Consistently with the results of WBSF and compression test, sex of animals was a significant factor of beef tenderness regardless of the breed or aging time. Generally, meat from bulls was tougher than that from heifers. Obtained values are shown in Table 5; the lowest significant differences (5\% level) were $2.08 \mathrm{~N}$ for WBSF and $5.95 \mathrm{~N} \cdot \mathrm{cm}^{-2}$ for compression test. 
Table 4. Compression test results influenced by animal breed and aging time of beef meat

\begin{tabular}{lcccc}
\hline $\begin{array}{l}\text { Aging time (weeks)/ } \\
\left.\text { Compression (N.cm }{ }^{-2}\right)\end{array}$ & 0 & 2 & 4 & 6 \\
\hline $\begin{array}{l}\text { Simmental (5 animals } \\
\text { per group) }\end{array}$ & $285.30 \pm 152.78$ & $182.19 \pm 47.93$ & $325.92 \pm 66.02$ & $202.43 \pm 27.63$ \\
$\begin{array}{l}\text { Charolais (21 animals } \\
\text { per group) }\end{array}$ & $267.09 \pm 82.57$ & $219.66 \pm 39.88$ & $227.75 \pm 66.95$ & $244.51 \pm 91.06$ \\
$\begin{array}{l}\text { Crossbreeds (21 animals } \\
\text { per group) }\end{array}$ & $242.01 \pm 91.94$ & $262.18 \pm 90.36$ & $225.20 \pm 59.77$ & $242.04 \pm 114.00$ \\
$\begin{array}{l}\text { Czech Fleckvieh (6 animals } \\
\text { per group) }\end{array}$ & $236.88 \pm 46.93$ & $238.24 \pm 96.36$ & $200.77 \pm 49.95$ & $167.07 \pm 42.76$ \\
$\begin{array}{l}\text { Galloway (19 animals } \\
\text { per group) }\end{array}$ & $218.91 \pm 73.28$ & $198.91 \pm 80.75$ & $228.12 \pm 70.17$ & $220.29 \pm 87.17$ \\
\hline
\end{tabular}

Table 5. Mean values of Warner-Bratzler tenderness and compression tenderness of beef meat from bulls and heifers

\begin{tabular}{lcc}
\hline Sex & Warner-Bratzler tenderness $(\mathrm{N})$ & Compression tenderness $\left(\mathrm{N} \cdot \mathrm{cm}^{-2}\right)$ \\
\hline Bulls & $104.39 \pm 0.73$ & $250.2 \pm 2.08$ \\
Heifers & $79.12 \pm 0.69$ & $215.6 \pm 1.98$ \\
\hline
\end{tabular}

We found relatively low correlation between tenderness measured by WBSF test and compression method $(\mathrm{r}=0.257, p \leq 0.001)$. As WBSF method is traditionally used for measuring the texture of beef and it could be assumed as a valid method, it is not possible to recommend the compression test as a complete substitution of the shear test. Nevertheless, it is a good complementary method to control beef quality.

Table 6. The effect of aging time of meat on the cooking loss of meat juice in all groups of animals

\begin{tabular}{cc}
\hline Aging time (weeks) & Cooking loss of meat juice (\%) \\
\hline 0 & $25.3 \pm 0.08^{\mathrm{a}}$ \\
2 & $32.2 \pm 0.08^{\mathrm{b}}$ \\
4 & $32.2 \pm 0.08^{\mathrm{b}}$ \\
6 & $34.00 \pm 0.08^{\mathrm{c}}$ \\
\hline
\end{tabular}

Means with different superscript are significantly different $(p \leq 0.001)$
Cooking loss of meat juice

As evident from Table 6, cooking loss of meat juice was changing in time. There was a significant $(p \leq 0.001)$ increase of cooking loss of meat juice during aging. The average loss right after slaughter was as high as $25.3 \%$ and after 6 weeks of aging average loss reached the value of $34.0 \%$. Our experiment also proved higher cooking loss of meat juice for bulls $(32.9 \%)$ than for heifers $(29.01 \%)$.

\section{Discussion}

Warner-Bratzler test

The evident increase of tenderness in our study was after 14 days of aging when the state of rigor mortis passed. The increase at following aging intervals was lower and meat was more uniform although the improvement was still significant. Also according to the findings of the study by Bratcher et al. (2005) and Maria et al. (2003), the majority of improvements in WBSF values of the beef muscles occurred by 14 days post mortem. Belew et al. (2003) tested 14 days aged beef and quantified the WBSF tenderness of $\mathrm{m}$. longissimus lumborum $3.4 \mathrm{~kg}(33.32 \mathrm{~N})$ and $\mathrm{m}$. longissimus thoracis $3.5 \mathrm{~kg}(34.3 \mathrm{~N})$, which is considerably lower shear force than in our results. Brewer et al. (2008) provided the conclusion that WBSF decreased $13 \%$ of initial shear value during the first 7 days of aging 
and additional $17 \%$ in the next 7 days, which is a reduction comparable to our results. Oliete et al. (2005) detected a significant reduction of the meat WBSF in beef with the aging time for meat under vacuum from the $1^{\text {st }}$ to the $21^{\text {st }}$ day $(38.2 \%)$. Our study found the decrease of $40.79 \%$ of WBSF after 4 weeks of aging. Lu et al. (1999) proved that aging for 2 weeks had a significant effect on WBSF in beef. The shear force decreased from $70.93 \mathrm{~N}$ after slaughter to $62.18 \mathrm{~N}$ in beef aged for 2 weeks. Beef in our experiment attained these values only after 6 weeks of aging.

According to Sanudo et al. (2004) breed had a significant effect on the WBSF measurements. But they detected that these differences among breeds were significant at short aging times, but disappeared at 21 days, and implied that longer aging times tend to homogenise the product. We did not come to the same conclusion, as at the end of the aging period there were still significant differences between the breeds. Sochor et al. (2005) found the lowest shear force for Czech Fleckvieh $(84.58 \mathrm{~N})$ followed by Charolais $(86.63 \mathrm{~N})$, Simmental $(110.98 \mathrm{~N})$. These values do not entirely correspond with our findings, partly because Sochor et al. (2005) concentrated on the methodology and did not involve aging in the study design.

\section{Compression test}

Our results agree with Sochor et al. (2005) who found significant differences $(p \leq 0.05)$ between Charolais $\times$ Czech Fleckvieh and Czech Fleckvieh $\times$ Simmental breeds measured by the compression test. Sex of animals was a significant factor of beef tenderness in our study. To the same conclusion came also other scientists (Pipek et al. 2003; Jeleníková et al. 2008). Conversely, Wulf et al. (1996) reported that steaks from heifer carcasses had higher shear force values than steaks from steer carcasses. But in this study a large amount of androgens was administrated to heifers, which could influence the texture of meat. Hedrick et al. (1969) also found no significant differences in WBSF values between sex groups. Prost et al. (1975) did not identify sex of animals as a significant factor in meat tenderness. Warner-Bratzler test was proved to have better predicative ability than compression test. By contraries, Ruiz de Huidobro et al. (2005) concluded that regarding correlations obtained between sensory and instrumental texture indicators in cooked meat, tenderness was better predicted by the Texture Profile Analysis (a double compression cycle) than by the WBSF method.

Despite of the apparent evidence of the utility of aging for improving tenderness of beef obtained in our study, there is still a problem of insufficiently aged beef in the Czech market. Beef is usually aged only for few days. To improve consumer acceptance and willingness to buy beef, aging should be recommended as a processing control point for the meat industry. The instrumental methods of tenderness measuring proved to be a useful tool for control of the quality and the state of maturity of meat.

\section{Vliv plemene, pohlaví a doby zrání na křehkost hovězího masa}

Naše studie byla provedena za účelem zhodnocení vlivu produkčních faktorů (plemeno, pohlaví) a doby zrání na texturní vlastnosti bovinního muscullus longissimus lumborum et thoracis za použití instrumentálního měření křehkosti masa. Hovězí maso pocházelo ze 72 zvířat (34 býků, 38 jalovic) plemen Galloway, Simmental, Charolais, Český strakatý skot a jejich kř́ižence. Průměrný porážkový věk byl 613 dní a průměrná živá váha $522 \mathrm{~kg}$. Křehkost masa byla měřena před zráním a po 14, 28 a 42 dnech zrání. Instrumentální křehkost byla charakterizována Warner-Bratzlerovým střižním testem a kompresním testem na přistroji Tira-test. Byla hodnocena ztráta masné štávy při tepelném opracování. Analýza rozptylu na hladině významnosti $5 \%$ prokázala, že všechny testované faktory (plemeno, pohlaví a doba zrání) měly vliv na křehkost masa. Střižní síla klesala v průběhu zrání a korelace mezi Warner-Bratzlerovým a kompresním testem byla 0.257 ( $p \leq 0.001)$. 
Rozdíly v křehkosti byly nalezeny také mezi jednotlivými plemeny. Nejvyšší počáteční střižná síla byla naměřena u Simmental $(151.98 \mathrm{~N})$ a u tohoto plemene bylo zaznamenáno nejméně výrazné zlepšení textury během zrání. Podle výsledků kompresního testu byla lepší křehkost u Českého strakatého skotu a Galloway než u plemene Simmental, Charolais a kříženců. U býků i jalovic byl pozorován obdobný průběh zrání, ale maso býků bylo průkazně $(p \leq 0.001)$ méně křehké než maso jalovic. Pozorován byl také statisticky prùkazný $(p \leq 0.001)$ nárůst ztráty št'ávy tepelným opracováním z $25.3 \%$ po porážce na $34.0 \%$ po celé době zrání. Výsledky výzkumu se mohou uplatnit při rozhodnutí, zda určitá plemena skotu mohou produkovat zaručeně křehké maso s náležitým průběhem zrání. Z výsledků studie vyplývá, že zvláštní naléhavost má vliv zrání na křehkost masa, protože se zřetelně předčí vliv plemene a pohlaví zvířat. Práce také navrhuje prodloužení doby zrání na 6 týdnů, aby byla zajištěna správná křehkost masa.

\section{Acknowledgement}

This study was funded by the Ministry of Education, Youth and Sports of the Czech Republic (Project MSM $2678846201)$.

\section{References}

Belew JB, Brooks JC, McKenna DR, Savell JW 2003: Warner-Bratzler shear evaluations of 40 bovine muscles. Meat Sci 64: 507-512

Bratcher CL, Johnson DD, Littell RC, Gwartney BL 2005: The effects of quality grade, aging, and location within muscle on Warner-Bratzler shear force in beef muscles of locomotion. Meat Sci 70: 279-284

Brewer S, Novakofski J 2008: Consumer sensory evaluations of aging effects on beef quality. J Food Sci 73: $78-82$

Caine WR, Aalhus, JL, Best DR, Dugan MER, Jeremiah LE 2003: Relationship of texture profile analysis and Warner-Bratzler shear force with sensory characteristics of beef next term rib steaks. Meat Sci 64: 333-339

Czech Statistical Office 2010: Consumption of meat in terms of carcass weight (annual per capita averages) in 2009. Retrieved April 132011 from http://www.czso.cz/csu/2010edicniplan.nsf/t/EA0049D17E/\$File/30041001.pdf

Hedrick HB, Thompson GB, Krause GF 1969: Comparison of feedlot performance and carcass characteristics of calf-cib bulls, steers and heifers. J Anim Sci 29: 687-694

Jeleníková J, Pipek P, Staruch L 2008: The influence of ante-mortem treatment on relationship between $\mathrm{pH}$ and tenderness of beef. Meat Sci 80: 870-874

Koohmaraie M 1994: Muscle proteinases and meat aging. Meat Sci 36: 93-104

Koohmaraie M, Wheeler TL, Shackelford SD 1995: Beef tenderness: regulation and prediction. USDA-ARS U. S. Meat Animal Research Center 9: 1-25

Lepetit J 2008: Collagen contribution to meat toughness: theoretical aspects. Meat Sci 80: 960-967

Lu R, Chen YR 1999: Shear properties and Warner-Bratzler tenderness measurement of beef. J Texture Stud 30: $361-375$

Maria GA, Villarroel M, Sanudo C, Olleta JL, Gebresenbet G 2003: Effect of transport time and ageing on aspects of beef quality. Meat Sci 65: 1335-1340

Oliete B, Moreno T, Carballo JA, Varela A, Monserrat L, Sanchez L 2005: Influence of ageing time on the quality of yearling calf meat under vacuum. Eur Food Res Technol 220: 489-493

Parrish FC 2009: Aging of beef. Beef USA Retrieved January 122010 from http:/www.goodcooking.com/steak/ aging/aging.htm

Pipek P, Haberl A, Jeleníková J 2003: Influence of slaughterhouse handling on the quality of beef carcasses. Czech J Anim Sci 9: 371-378

Prost E, Pelczynska E, Kotula AW 1975: Quality characteristics of bovine meat. II. Beef tenderness in relation to individual muscles, age and sex of animals and carcass quality grade. J Anim Sci 41: 541-547

Ruiz de Huidobro F, Miguel E, Blazquez B, Onega E 2005: A comparison between two methods (Warner-Bratzler and texture profile analysis) for testing either raw meat or cooked meat. Meat Sci 69: 527-536

Sanudo C, Macie ES, Olleta JL, Villarroel M, Panea B, Alberti P 2004: The effects of slaughter weight, breed type and ageing time on beef meat quality using two different texture devices. Meat Sci 66: 925-932

Sochor J, Simeonovova J, Subrt J, Buchar J 2005: Effect of selected fattening performance and carcass value traits on textural properties of beef. Czech J Anim Sci 50: 81-88

Wulf DM, Tatum JD, Green RD, Morgan JB, Golden BL, Smith GC 1996: Genetic influences on beef longissimus palatability in Charolais- and Limousin-sired steers and heifers. J Anim Sci 74: 2394-2405 